\title{
PENGARUH ENZIM POLIGALAKTURONASE DAN GELATIN DALAM KLARIFIKASI SARI BUAH NAGA SUPER MERAH (Hylocereus costaricensis)
}

\author{
INFLUENCE OF POLYGALACTURONASE ENZYME AND GELATIN IN THE \\ CLARIFICATION OF SUPER RED DRAGON FRUIT JUICE (Hylocereus costaricensis)
}

\author{
Esti Widowati, Nur Her Riyadi Parnanto, Muthoharoh \\ Program Studi Ilmu Teknologi Pangan, Fakultas Pertanian, Universitas Sebelas Maret \\ Jl. Ir. Sutami 36A Kentingan Jebres Surakarta 57126 \\ Email : esti_widowati@yahoo.com, estiwidowati@staff.uns.ac.id
}

Diserahkan [31 Maret 2020]; Diterima [21 Juli 2020]; Dipublikasi [14 Agustus 2020]

\begin{abstract}
The aimed of this research was to determine the effect of polygalacturonase (PG) enzyme from Bacillus licheniformis strain GD2A AR2 (0.09\% and 0.1\%) with gelatin (1\% and $1.5 \%)$ in super red dragon fruit juice clarification against to $\mathrm{pH}$, total soluble solids, viscosity, and transmittance. Polygalacturonase enzyme hydrolyze pectin into galacturonic acid that it may reduce the $\mathrm{pH}$ and viscosity of super red dragon fruit juice. Decrease in $\mathrm{pH}$ caused the decrease of total soluble solids of super red dragon fruit juice. Degradation of pectin increased transmittance of super red dragon fruit juice. Gelatin in fruit juice increased $\mathrm{pH}$, total soluble solids, viscosity, and transmittance. Samples with polygalacturonase enzyme 0.1\%, total soluble solid $15.6667^{\circ}$ Brix, viscosity $10.3957 \mathrm{cP}$, transmittance 0.8 (\% T535), and the $\mathrm{pH}$ value of 3.97 were selected sample. Polygalacturonase enzyme $0.1 \%$ may reduced the value of total soluble solids, decreased viscosity values, increased the value of transmittance, and reduced the $\mathrm{pH}$ value of super red dragon fruit juice. Gelatin can clear the juice by absorbing the contents that can cause cloudy juice like tannins. Gelatin has an amino group that is able to form complex compounds by binding to pectin in fruit juice. This research was conducted into $P G$ enzyme production, PG enzyme partial purification, variation of enzyme concentration and gelatin, super red dragon fruit juice clarification, and determination for the best treatment. Best $\mathrm{pH}$ value in the samples with polygalacturonase enzyme $0 \%$ and $1.5 \%$ gelatin was 4.11 (control 4.8). The highest transmittance value in the sample with polygalacturonase enzyme $0.1 \%$ and $1.5 \%$ gelatin was 1 (\% T535). Gelatin and polygalacturonase enzyme worked together in improving the transmittance value in the clarification super red dragon fruit juice simultaneously with increasing the used of concentration enzyme and gelatin.
\end{abstract}

Key words : Clarification, gelatin, pectin, polygalacturonase enzyme, super red dragon fruit juice

\begin{abstract}
ABSTRAK
Tujuan dari penelitian ini adalah untuk mengetahui pengaruh penggunaan enzim poligalakturonase (PG) isolat Bacillus licheniformis strain GD2a AR2 ( $0,09 \%$ dan $0,1 \%)$ dengan gelatin $(1 \%$ dan $1,5 \%)$ dalam klarifikasi sari buah naga super merah terhadap parameter $\mathrm{pH}$, total padatan terlarut, viskositas, dan transmitansi. Enzim poligalakturonase menghidrolisis pektin menjadi asam galakturonat sehingga dapat menurunkan $\mathrm{pH}$ dan viskositas sari buah naga super merah. Penurunan $\mathrm{pH}$ dapat menurunkan total padatan sari buah naga super merah. Degradasi pektin meningkatkan transmitansi sari buah naga super merah. Sedangkan penambahan gelatin dapat meningkatkan $\mathrm{pH}$, total padatan terlarut, viskositas, dan transmitansi sari buah. Tahapan penelitian ini adalah produksi enzim PG, purifikasi parsial enzim PG, penentuan variasi konsentrasi enzim PG dan gelatin, klarifikasi sari buah naga super merah, dan penentuan perlakuan terbaik. Sampel dengan penambahan enzim poligalakturonase $0,1 \%$ dengan nilai total padatan terlarut $15,6667^{\circ}$ Brix, nilai viskositas $10,3957 \mathrm{cP}$, nilai transmitansi 0,8 (\%T535), dan nilai pH 3,97 merupakan sampel terpilih. Penambahan enzim poligalakturonase $0,1 \%$ dapat menurunkan nilai total padatan terlarut, menurunkan nilai viskositas, meningkatkan nilai transmitansi, dan menurunkan nilai $\mathrm{pH}$ sari buah naga super merah. Gelatin dapat menjernihkan sari buah dengan menyerap kandungan-kandungan yang dapat menyebabkan sari buah keruh seperti tanin. Gelatin memiliki gugus amino yang mampu membentuk senyawa kompleks dengan cara mengikat pektin pada sari buah. Nilai $\mathrm{pH}$ terbaik pada sampel dengan penambahan enzim poligalakturonase $0 \%$ dan gelatin $1,5 \%$ dengan nilai 4,11 (kontrol 4,8). Nilai transmitansi tertinggi pada sampel dengan penambahan enzim poligalakturonase $0,1 \%$ dan gelatin 1,5\% dengan nilai transmitansi 1 (\%T535). Cara kerja gelatin dan enzim poligalakturonase bersinergi dalam meningkatkan nilai transmitansi pada klarifikasi sari buah naga super merah dengan seiring bertambahnya konsentrasi enzim dan gelatin yang digunakan.
\end{abstract}

Kata kunci: enzim poligalakturonase, gelatin, klarifikasi, sari buah naga super merah 


\section{PENDAHULUAN}

Buah naga atau dragon fruit mempunyai kandungan zat bioaktif yang bermanfaat bagi tubuh diantaranya antioksidan (dalam asam askorbat, betakaroten, dan antosianin), serat pangan dalam bentuk pektin, beberapa mineral seperti kalsium, fosfor, besi, dan vitamin seperti vitamin $\mathrm{B} 1$, vitamin $\mathrm{B} 2$, vitamin $\mathrm{B}$, serta vitamin $C$. Buah ini juga memiliki kadar gula sekitar $13-15^{0}$ Brix dan aktivitas antioksidan pada minuman fermentasi buah naga super merah sebesar $42,5474 \%$, hasil ini lebih tinggi dibanding dengan aktivitas antioksidan pada produk sirup dari ekstrak daging buah naga dengan aktivitas antioksidan sebesar $19,04 \%$. Buah naga super merah lebih mudah dibudidaya dan lebih populer karena daging buahnya yang bewarna lebih merah dibanding jenis lainnya. Buah naga segar tidak dapat disimpan lama karena kadar airnya yang tinggi yaitu $90 \%$ dengan umur simpan 7-10 hari pada suhu $14^{\circ} \mathrm{C}$ sehingga diperlukan pengolahan lanjutan untuk mempertahankan kandungan gizi dan memperpanjang umur simpan. Salah satu pengolahan buah naga yaitu dengan dibuat sari buah (Farikha dkk., 2013) Berdasarkan Keputusan Kepala Badan POM HK00.05.52.4040 Tahun 2006 tentang Kategori Pangan mengatur definisi dan karakteristik dasar sari buah adalah cairan yang diperoleh dari bagian buah yang dapat dimakan yang dicuci, dihancurkan, dan dijernihkan dengan atau tanpa pasteurisasi. Sari buah adalah salah satu produk olahan buah-buahan yang telah lama dikenal. Industri sari buah buah-buahan tropis termasuk berkembang pesat beberapa tahun terakhir dengan laju mencapai $20 \%$ per tahun dan meningkat menjadi $54 \%$ pada tahun 2009 (Direktorat Jenderal Agro Industri dan Kimia, 2010). Sari buah naga merupakan minuman siap saji yang kaya gizi yang dibuat melalui proses penghancuran buah naga dengan jenis buah naga yang kandungan sari buahnya tinggi (Soedarya, 2013). Buah naga yang digunakan dalam penelitian ini yaitu buah naga super merah dari CV. Wana Bekti Handayani dengan kadar air 90\%. Kapasitas produksi sari buah naga super merah
CV.Wana Bekti Handayani yaitu 12.000 botol/bulan atau 80 ton/ha selama 4 tahun.

Dalam pembuatan sari buah terdapat proses klarifikasi untuk menjernihkan sari buah dan menghindari karakter seperti terjadinya pengendapan di dasar botol yang tidak diinginkan karena hal tersebut akan menurunkan penerimaan konsumen (Widowati dkk., 2019). Selain itu, proses klarifikasi ini penting karena dalam sari buah terdapat pektin yang merupakan polimer dari asam d-galakturonat yang dihubungkan dengan ikatan $\beta$-(1,4)-glukosida yang dapat menghasilkan endapan, pembentukan jelly, dan kekeruhan pada sari buah (Singh et al., 2012) sehingga dapat menganggu proses filtrasi (Widowati dkk., 2019) dan mengurangi hasil rendemen sari buah (Sharma et al., 2014).

Karakteristik sari buah naga super merah cenderung keruh karena banyak padatan terlarut, kental, dan sedikit asam. Masalah yang timbul dalam pembuatan sari buah naga super merah adalah adanya kekentalan sari buah naga super merah yang dapat mengganggu proses filtrasi dan mengurangi hasil rendemen sari buah naga super merah sehingga diperlukan proses klarifikasi. Salah satu proses klarifikasi yang dapat dilakukan adalah dengan enzim poligalakturonase. Enzim poligalakturonase memiliki kelebihan dalam mengklarifikasi sari buah dengan menghidrolisis asam pektat secara acak menjadi asam galakturonat dan tidak menghasilkan residu metoksil dibandingkan dengan enzim pektinesterase yang menghasilkan residu metoksil (Utami dkk., 2015). Enzim poligalakturonase menghidrolisis ikatan glikosidik pektat dengan mekanisme pemisahan, memiliki sifat thermostable, optimum $\mathrm{pH} \quad 3-6$ serta memiliki nilai $\mathrm{K}_{\mathrm{m}}$ rendah (Widowati et al., 2017). Depolimerisasi pektin dengan poligalakturonase dapat menurunkan viskositas sari buah dan memberikan aroma buah matang karena poligalakturonase bekerja pada asam poligalakturonat (Widowati dkk., 2019). Dari penelitian yang telah dilakukan 'Aliaa et al., (2010), enzim Pectinex CLEAR (dari Aspergillus aculeatus dan Aspergillus niger) pada konsentrasi 0,09\% dan Pectinex Ultra SP-L (dari 
Aspergillus niger) pada konsentrasi $0,1 \%$ terbukti meningkatkan karakteristik fisikokimia yang mengarah pada sari buah dengan hasil yang lebih tinggi, keasaman tinggi, total padatan terlarut yang lebih tinggi, dan meningkatkan kejernihan serta kenampakan warna sari buah. Perlakuan enzimatik juga mengurangi $\mathrm{pH}$ dan viskositas sari buah. Selain itu juga meningkatkan komponen gizi dalam sari buah seperti protein, karbohidrat, dan jumlah polifenol. Penelitian ini menunjukkan pengaruh aplikasi pektinase pada komposisi kimia, vitamin $\mathrm{C}$, dan jumlah polifenol. Penggunaan pektinase sebagai alat bantu pengolahan dalam produksi sari buah terbukti menjadi langkah penting dalam rangka meningkatkan efisiensi seluruh sistem.

Proses klarifikasi juga dapat dilakukan dengan penambahan gelatin. Gelatin berasal dari jaringan kolagen kulit hewan dan memiliki sifat mudah terdispersi dalam air. Konsentrasi gelatin yang direkomendasikan dalam produk minuman sari buah antara 0,51,5\% (Farikha dkk., 2013). Gelatin dapat digunakan sebagai penjernih ketika gelatin tersebut didenaturasi. Denaturasi merupakan suatu perubahan struktur sekunder, tersier, dan kuartener terhadap molekul protein, tanpa terjadinya pemecahan ikatan-ikatan kovalen. Denaturasi protein dapat disebabkan oleh panas, $\mathrm{pH}$, senyawa kimia (urea dan garam guanidia), mekanik, dan sebagainya. Pemekaran atau pengembangan molekul protein yang terdenaturasi akan membuka gugus reaktif yang ada pada rantai polipeptida. Selanjutnya akan terjadi pengikatan kembali pada gugus reaktif yang sama atau yang berdekatan. Bila unit ikatan yang terbentuk cukup banyak sehingga protein tidak lagi terdispersi sebagai suatu koloid, maka protein tersebut mengalami koagulasi. Gelatin dapat menjernihkan sari buah dengan menyerap kandungankandungan yang dapat menyebabkan sari buah keruh seperti tanin. Gelatin memiliki gugus amino yang mampu membentuk senyawa kompleks dengan cara mengikat pektin pada sari buah. Pektin mengandung gugus metil ester yang bermuatan negatif sedangkan gugus amino pada gelatin bermuatan positif yang kemudian berikatan membentuk senyawa kompleks yang mempu mengikat pektin sehingga mampu mencegah terjadinya pengendapan (Khalil, 2013).

Menurut Khalil (2013), klarifikasi enzimatik sari buah dengan menambahkan $0,01 \%$ gelatin telah mengurangi setengah waktu klarifikasi sari buah. Peningkatan konsentrasi enzim dan gelatin menyebabkan peningkatan nilai \%T690. Konsentrasi enzim (25 IU) dengan gelatin $(0,01 \%)$ telah memberikan hasil yang baik $(\mathrm{p}<0,05)$ untuk klarifikasi sari buah (\% nm T690). Penggunaan enzim dan gelatin bertujuan untuk meningkatkan efisiensi dalam klarifikasi sari buah daripada menggunakan enzim saja.

Farikha dkk. (2013) melaporkan bahwa klarifikasi sari buah naga merah (Hylocereus polyrhizus) dengan gelatin pada konsentrasi $1 \%$ dan 1,5\% merupakan konsentrasi terbaik yang dilihat dari beberapa parameter saat diujikan pada sari buah naga merah, sedangkan penggunaan enzim poligalakturonase dari penelitian Widowati et al.,(2017) menghasilkan isolat Bacillus licheniformis strain GD2a AR2 dengan aktivitas enzim poligalakturonase sebesar $0,123 \mathrm{U} / \mathrm{ml}$ dengan variasi konsentrasi $0,09 \%$ dan $0,1 \%$ pada klarifikasi sari buah jeruk keprok garut. 'Aliaa et al., (2010) melaporkan konsentrasi dua enzim komersial untuk mengetahui pengaruhnya terhadap beberapa karakteristik fisikokimia pada sari buah naga merah. Pemilihan isolat Bacillus licheniformis strain GD2a AR2 juga dikarenakan enzim isolat Bacillus licheniformis strain GD2a AR2 aktif stabil pada kisaran pH 4-7 dan optimum pada pH 6. Selain itu enzim poligalakturonase dari Bacillus licheniformis strain GD2a AR2 stabil pada kisaran suhu $50-60^{\circ} \mathrm{C}$ dan optimum pada suhu $60^{\circ} \mathrm{C}$, hal ini menunjukan bahwa enzim tersebut merupakan enzim thermostabil dan dapat diaplikasikan pada industri sari buah. Penelitian ini bertujuan untuk mengetahui pengaruh penggunaan enzim poligalakturonase isolat Bacillus licheniformis strain GD2a AR2 pada konsentrasi $0,09 \%$ dan $0,1 \%$ dengan gelatin pada konsentrasi $1 \%$, dan $1,5 \%$ terhadap klarifikasi sari buah naga super merah 
(Hylocereus costaricensis) terhadap parameter $\mathrm{pH}$, total padatan terlarut, viskositas, dan transmitasi.

\section{METODE PENELITIAN}

\section{Bahan}

Sampel yang digunakan dalam penelitian ini yaitu buah naga super merah (Hylocereus costaricensis) yang kulitnya berwarna merah disertai sisik atau sulur berwarna merah, daging buah berwarna sangat merah bertabur biji-biji berwarna hitam dengan berat rata-rata 300-500 gram. Sampel diperoleh dari CV. Wana Bekti Handayani, Dukuhan, Prampalan, Masaran, Sragen dengan umur panen sejak tanam sampai berbuah kira-kira 8-12 bulan. Klarifikasi sari buah naga super merah menggunakan enzim poligalakturonase isolat bakteri Bacillus licheniformis strain GD2a AR2 konsentrasi $0,09 \%$; 0,1\% yang memiliki aktivitas enzim kasar $0,123 \mathrm{U} / \mathrm{ml}$, stabil pada kisaran $\mathrm{pH} 4-7$, optimum pada $\mathrm{pH}$ 6, stabil pada suhu $50-60^{\circ} \mathrm{C}$, dan optimum pada suhu $60^{\circ} \mathrm{C}$, dan gelatin konsentrasi $1 \% ; 1,5 \%$. Bahan analisis yang digunakan dalam penelitian antara lain aquades, alkohol $90 \%$, amonium sulfat $\left(\left(\mathrm{NH}_{4}\right)_{2} \mathrm{SO}_{4}\right)$, buffer asetat

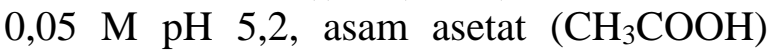
(MERCK, Germany), natrium asetat $\left(\mathrm{CH}_{3} \mathrm{COONa}\right)$ (MERCK, Germany), barium klorida $\left(\mathrm{BaCl}_{2}\right)$ (MERCK, Germany), yeast extract (OXOID, UK), disodium hidrogen fosfat $\left(\mathrm{Na}_{2} \mathrm{HPO}_{4}\right)$ (MERCK, Germany), potasium dihidrogen fosfat $\left(\mathrm{KH}_{2} \mathrm{PO}_{4}\right)$ (MERCK, Germany), magnesium sulfat (MgSO4.7H2O) (MERCK, Germany), kalium klorida ( $\mathrm{KCl})$ (MERCK, Germany), pektin citrus (Sigma-Aldrich, Singapore), bacteriological agar (Difco, USA).
Alat
Alat-alat yang digunakan dalam analisis penelitian yaitu neraca analitik (Mettler Toledo), juicer (HR1810; $220 \mathrm{~W}$; 0,75 L), aluminium foil, autoklaf (Selecta), inkubator (Selecta), shaker inkubator, vortex (Heidolph), sentrifuge (Hettich), membran selofan cut off $12 \mathrm{kDa}$, magnetic stirer, hand refractometer (ATAGO), viskometer (Ostwald), spektrofotometer UV-Vis

(Shimadzu), pH meter, piknomometer, dan peralatan gelas yang umum digunakan dalam laboratorium.

\section{Tahapan Penelitian}

Produksi, isolasi, dan ekstraksi enzim poligalakturonase (Widowati et al; 2017)

\section{Produksi enzim poligalakturonase}

Enzim poligalakturonase diproduksi dengan cara pembuatan stok inokulum $10 \%$, yaitu sebanyak $1 \mathrm{ml}$ inokulum diinokulasikan ke dalam $10 \mathrm{ml}$ media pektin cair kemudian diinkubasi dalam inkubator shaker supaya selalu homogen dan persebaran oksigen merata yaitu dengan kecepatan $144 \mathrm{rpm}$ pada suhu $55^{\circ} \mathrm{C}$ selama 24 jam. Inokulum $10 \%$ diinokulasi pada $90 \mathrm{ml}$ media produksi enzim dan diinkubasi dalam inkubator shaker pada suhu $55^{\circ} \mathrm{C}$ sampai fase logaritma sesuai waktu hasil kurva pertumbuhan isolat Bacillus licheniformis strain Gd2a AR2 adalah 10 jam.

\section{Isolasi dan ekstraksi enzim} poligalakturonase

Isolasi protein dapat dilakukan dengan cara sentrifugasi pada kecepatan yang tinggi (5000-10000 rpm) atau presipitasi menggunakan garam seperti ammonium sulfat. Kedua metode tersebut bertujuan untuk menghilangkan molekul atau partikel pengotor dari sel seperti organel sel, karbohidrat atau lipid yang tidak diinginkan agar diperoleh isolat protein yang murni. Pada penelitian ini kultur isolat yang telah mencapai waktu produksi (fase logaritma) kemudian disentrifugasi dengan kecepatan $6000 \mathrm{rpm}$ selama 15 menit pada suhu $4^{0} \mathrm{C}$ sehingga menghasilkan supernatan sebanyak $90 \mathrm{ml}$ yang mengandung enzim kasar.

\section{Pemurnian parsial enzim poligalakturonase (Modifikasi Widowati $e t$ al., 2017)}

\section{Presipitasi amonium sulfat}

Presipitasi enzim dilakukan dengan amonium sulfat fraksi kejenuhan $50 \%$. Proses fraksinasi bertujuan untuk memekatkan atau menjenuhkan larutan sehingga diperoleh larutan pekat yang mengandung endapan protein. Enzim 
isolat Bacillus licheniformis strain $\mathrm{Gd} 2 \mathrm{a}$ AR2 memiliki aktivitas tertinggi pada fraksi kejenuhan 50\% sebesar 0,09 U/ml.

Supernatan dipresipitasi d engan fraksinasi amonium sulfat $50 \%$. Pada tabel konversi nilai untuk kejenuhan 50\% adalah 313 gram per liter. Pada penelitian ini diperoleh $90 \mathrm{ml}$ supernatan, sehingga amonium sulfat yang ditambahkan sebanyak $0,09 \mathrm{~L}$ x $313 \mathrm{gram} / \mathrm{L}=28,17$ gram

Presipitasi amonium sulfat $50 \%$ disertai perlakuan agitasi dan dibiarkan selama 24 jam pada suhu $4^{0} \mathrm{C}$. Setelah setimbang, supernatan yang telah dipresipitasi disentrifugasi pada 12.000 rpm pada $4^{0} \mathrm{C}$ selama 10 menit sehingga menghasilkan pellet (protein) sedangkan supernatannya tidak digunakan. Pellet yang mengandung protein enzim dan non enzim kemudian ditambah buffer asam asetat $0,05 \mathrm{M} \mathrm{pH}$ 5,2 dengan perbandingan 1:1 untuk kemudian dilakukan proses dialisis.

\section{Dialisis}

Dalam proses dialisis digunakan membran semipermeabel untuk menahan molekul-molekul protein, sedangkan molekul yang lebih kecil seperti garam dan air dapat melewati membran tersebut. Pada penelitian, membran semipermeabel yang digunakan adalah selofan yang dapat memisahkan protein dengan berat molekul lebih kecil dari $12 \mathrm{kDa}$ dan partikel non protein. Hasil presipitasi didialisis dalam kantung membran selofan cut off $12 \mathrm{kDa}$ berisi protein (enzim) dan larutan buffer asetat $0,05 \mathrm{M} \mathrm{pH} 5,2$ serta diaduk dengan magnetic stirer selama 24 jam dalam baskom yang diberi es dengan pengaturan suhu konstan $4^{0} \mathrm{C}$. Protein dalam kantong selofan bebas garam presipitasi dan kontaminan lainnya yang ditandai dengan indikator $\mathrm{BaCl}_{2}$ dimana akan terbentuk endapan putih $\left(\mathrm{BaSO}_{4}\right)$ karena kelarutannya yang rendah. Pergantian buffer pada proses dialisis ini dilakukan selama 8 jam sekali selama 24 jam dialisis dan diperoleh enzim poligalakturonase isolat Bacillus licheniformis strain GD2a AR2 murni parsial sebanyak 23,9 ml.
Penentuan variasi konsentrasi enzim poligalakturonase dan gelatin serta pembuatan sari buah naga super merah ('Aliaa, et al., 2010; Farikha dkk., 2013)

1. Penentuan konsentrasi enzim poligalkturonase ('Aliaa, et al., 2010; Widowati et al., 2017; Widowati dkk., 2019)

Penggunaan enzim poligalakturonase dihasilkan dari penelitian Widowati et al., (2017) dari limbah kulit jeruk keprok Garut dan limbah sayuran yang diperoleh 14 isolat yang menghasilkan poligalakturonase dan telah diaplikasikan pada sari buah jeruk keprok Garut. Pada penelitian tersebut diambil isolat yang memiliki aktivitas enzim kasar tertinggi yaitu isolat Bacillus licheniformis strain GD2a AR2 dengan aktivitas enzim sebesar $0,123 \mathrm{U} / \mathrm{ml}$. Penentuan variasi konsentrasi enzim poligalakturonase isolat Bacillus licheniformis strain GD2a AR2 berdasarkaan penelitian 'Aliaa, et al. (2010).

\section{Penentuan konsentrasi gelatin (Farikha dkk, 2013)}

Penentuan variasi konsentrasi gelatin berdasarkaan penelitian Farikha dkk (2013) tentang pengaruh jenis dan konsentrasi bahan penstabil alami terhadap karakteristik fisikokimia sari buah naga merah (Hylocereus polyrhizus) selama penyimpanan. Penelitian ini bertujuan untuk mengetahui pengaruh jenis dan konsentrasi bahan penstabil terhadap sifat fisikokimia (total padatan terlarut, viskositas, stabilitas, $\mathrm{pH}$, aktivitas antioksidan, dan kadar vitamin C) sari buah naga merah selama penyimpanan. Bahan penstabil yang digunakan ialah gelatin dan kitosan dengan konsentrasi $0,5 \%, 1 \%$, dan $1,5 \%$ dengan lama penyimpanan 6 hari pada suhu ruang. Hasil penelitian menunjukkan bahwa total padatan terlarut tertinggi pada penambahan gelatin $1,5 \%\left(13,19^{0}\right.$ Brix $)$, sedangkan terendah pada kitosan $0,5 \%$ $\left(12,59^{0}\right.$ Brix $)$ dan kontrol $\left(12,32^{0}\right.$ Brix $)$. Viskositas tertinggi terjadi pada gelatin $1,5 \% \quad(2,44 \mathrm{cP})$, terendah pada kitosan $0,5 \% \quad(3,35 \mathrm{cP})$ dan kontrol $(2,22 \mathrm{cP})$. 
Stabilitas tertinggi pada penambahan gelatin $1,5 \%$ (91\%), terendah pada kitosan $0,5 \%(51 \%)$ dan kontrol $(45,75 \%)$. Nilai $\mathrm{pH}$ tertinggi pada kitosan $1,5 \% \quad(5,22)$, terendah pada gelatin $0,5 \%(4,54)$ dan kontrol $(4,43)$. Aktivitas antioksidan tertinggi pada kitosan 1,5\% (57,33\%), terendah pada gelatin $1,5 \%(34,80 \%)$ dan kontrol (29,76\%). Kadar vitamin C tertinggi pada gelatin $1,5 \% \quad(11,55$ $\mathrm{mg} / 100 \mathrm{~g})$, terendah kitosan 1,5\% (10,56 $\mathrm{mg} / 100 \mathrm{~g})$ dan kontrol $(9,57 \mathrm{mg} / 100 \mathrm{~g})$. Selama penyimpanan 6 hari pada suhu ruang terjadi penurunan pada semua perlakuan (gelatin, kitosan, dan kontrol). Semakin tinggi konsentrasi penstabil maka semakin tinggi total padatan terlarut, viskositas, stabilitas, $\mathrm{pH}$, dan aktivitas antioksidan. Sedangkan kadar vitamin C semakin meningkat ketika konsentrasi gelatin semakin tinggi, tetapi semakin menurun ketika konsentrasi kitosan dinaikkan.

1. Penentuan variasi konsentrasi enzim poligalakturonase dan gelatin ('Aliaa, $e t$ al., 2010; Farikha dkk., 2013)

Penggunaan enzim poligalakturonase dihasilkan dari penelitian Widowati et al., (2017) dari limbah kulit jeruk keprok Garut dan limbah sayuran yang diperoleh 14 isolat yang menghasilkan poligalakturonase yang telah diaplikasikan pada sari buah jeruk keprok Garut dan diabil isolat yang memiliki aktivitas enzim kasar tertinggi yaitu isolat Bacillus licheniformis strain GD2a AR2 dengan aktivitas enzim kasar sebesar 0,123 U/ml dengan variasi konsentrasi $0,09 \%$ dan $0,1 \%$ yang dari penelitian 'Aliaa et al. (2010) yang merupakan konsentrasi dua enzim komersial untuk mengetahui pengaruhnya terhadap beberapa karakteristik fisikokimia pada sari buah naga merah. Sedangkan konsentrasi gelatin yang digunakan dari penelitian Farikha dkk. (2013) yaitu gelatin konsentrasi terbaik $1 \%$ dan $1,5 \%$ yang dilihat dari beberapa parameter saat diujikan pada sari buah naga merah yaitu klarifikasi sari buah naga merah. Variasi konsentrasi enzim poligalakturonase yang digunakan seperti pada Tabel 1. yaitu Aa (enzim $0 \%$; gelatin $0 \%$ ), $\mathrm{Ab}$ (enzim $0 \%$; gelatin 1\%), Ac (enzim 0\%; gelatin 1,5\%), $\mathrm{Ba}$ (enzim $0,09 \%$; gelatin $0 \%$ ), $\mathrm{Bb}$ (enzim $0,09 \%$; gelatin $1 \%$ ), Bc (enzim 0,09\%; gelatin $1,5 \%$ ), $\mathrm{Ca}$ (enzim $0,1 \%$; gelatin $0 \%$ ), $\mathrm{Cb}$ (enzim $0,1 \%$; gelatin $1 \%$ ), dan Cc (enzim $0,1 \%$; gelatin 1,5\%) dengan 3 kali pengulangan dan 1 kali analisis.

Tabel 1 Rancangan Variasi Konsentrasi Enzim Poligalaturonase (PG) dan Gelatin

\begin{tabular}{lcccc}
\hline \multirow{2}{*}{$\begin{array}{l}\text { Enzim } \\
(\mathrm{PG})\end{array}$} & Pengulangan & \multicolumn{3}{c}{ Konsentrasi Gelatin } \\
\cline { 3 - 5 } & & $\begin{array}{r}0 \% \\
(\mathrm{a})\end{array}$ & $\begin{array}{r}1 \% \\
(\mathrm{~b})\end{array}$ & $\begin{array}{c}1,5 \% \\
(\mathrm{c})\end{array}$ \\
\hline $0 \%$ & 1 & $\mathrm{Aa} 1$ & $\mathrm{Ab} 1$ & $\mathrm{Ac} 1$ \\
$(\mathrm{~A})$ & 2 & $\mathrm{Aa} 2$ & $\mathrm{Ab} 2$ & $\mathrm{Ac} 2$ \\
& 3 & $\mathrm{Aa} 3$ & $\mathrm{Ab} 3$ & $\mathrm{Ac3}$ \\
& 1 & $\mathrm{Ba} 1$ & $\mathrm{Bb} 1$ & $\mathrm{Bc} 1$ \\
$0,09 \%$ & 2 & $\mathrm{Ba} 2$ & $\mathrm{Bb} 2$ & $\mathrm{Bc} 2$ \\
$(\mathrm{~B})$ & 3 & $\mathrm{Ba} 3$ & $\mathrm{Bb} 3$ & $\mathrm{Bc} 3$ \\
& 1 & $\mathrm{Ca} 1$ & $\mathrm{Cb} 1$ & $\mathrm{Cc} 1$ \\
$0,1 \%$ & 2 & $\mathrm{Ca} 2$ & $\mathrm{Cb} 2$ & $\mathrm{Cc} 2$ \\
$(\mathrm{C})$ & 3 & $\mathrm{Ca} 3$ & $\mathrm{Cb} 3$ & $\mathrm{Cc} 3$ \\
\hline
\end{tabular}

2. Pembuatan sari buah naga super merah (Modifikasi Farikha dkk, 2013; Widowati dkk., 2019)

Buah naga super merah yang sudah disortasi dari CV. Wana Bekti Handayani kemudian dicuci dan dipotong secara melintang dan kemudian diekstraksi dengan juicer. Juicer ini akan mengepres buah naga super merah melewati saringan untuk memisahkan sari buah dengan ampasnya sehingga diperoleh sari buah naga super merah. Karena volume sari buah naga super merah pada setiap sampel adalah $30 \mathrm{ml}$ maka jumlah buah naga super merah yang dibutuhkan untuk pengujian pada 4 parameter yaitu kurang lebih 1169 gram. Sari buah naga super merah masing-masing sebanyak $30 \mathrm{ml}$ pada 9 sampel dengan 3 kali pengulangan sampel ditambah enzim poligalakturonase Bacillus licheniformis strain GD2a AR2 (hasil presipitasi ammonium sulfat dan dialisis) pada kode sampel $\mathrm{Ba}, \mathrm{Bb}$, dan $\mathrm{Bc}$ sebesar $0,09 \%$ dan pada sampel $\mathrm{Ca}, \mathrm{Cb}$, dan Cc sebesar 0,1\%. Semua sampel divortex untuk menghomogenkan kondisi 
sampel untuk kemudian diinkubasi pada suhu $55^{\circ} \mathrm{C}$ selama 60 menit. Setelah itu dilakukan inaktivasi enzim dengan suhu $90^{\circ} \mathrm{C}$ selama 5 menit untuk kemudian sari buah naga super merah ditambahkan gelatin $1 \%$ pada kode sampel $\mathrm{Ab}, \mathrm{Bb}$, dan $\mathrm{Cb}$ dan $1,5 \%$ pada kode sampel $\mathrm{Ac}, \mathrm{Bc}$, dan $\mathrm{Cc}$ dalam suhu $70^{\circ} \mathrm{C}$ kemudian divortex untuk menghomogenkan kondisi sampel. Setelah itu semua sampel dibiarkan selama 25 menit dalam suhu ruang untuk kemudian diuji nilai $\mathrm{pH}(\mathrm{cP})$, Total Padatan Terlarut (TPT) ( $\left.{ }^{0} \mathrm{Brix}\right)$, viskositas (cp), dan transmitansi (\%T). Panduan pembuatan yang meliputi volume dan rendemen dapat dilihat pada Tabel 2.

Tabel 2 Pembuatan Sari Buah Naga Super Merah

\begin{tabular}{cccccc}
\hline \multirow{2}{*}{$\begin{array}{c}\text { Buah naga } \\
\text { super merah }\end{array}$} & $\begin{array}{c}\text { Berat Awal } \\
(\mathrm{g})\end{array}$ & $\begin{array}{c}\text { Berat Akhir } \\
(\mathrm{g})\end{array}$ & $\begin{array}{c}\text { Volume } \\
\text { Akhir }(\mathrm{ml})\end{array}$ & $\begin{array}{c}\text { Rendemen } \\
(\mathrm{b} / \mathrm{b})(\%)\end{array}$ & $\begin{array}{c}\text { Rendemen } \\
(\mathrm{v} / \mathrm{b})(\%)\end{array}$ \\
\cline { 2 - 6 } & 1725 & 1169 & 1000 & 67,768 & 57,971 \\
\hline
\end{tabular}

\section{Klarifikasi sari buah naga super merah}

\section{1. pH (Akesowan dan Choonhahirun, 2013)}

Pengukuran $\mathrm{pH}$ menggunakan $\mathrm{pH}-$ meter.

\section{Total Padatan Terlarut (Akesowan dan Choonhahirun, 2013)}

Total Padatan Terlarut (TPT) ditentukan dengan meneteskan sampel pada area uji alat hand refractometer. Hasil dapat dilihat pada skala yang tepat pada tanda batas pengamatan.

\section{Viskositas (Widowati dkk., 2019)}

Penentuan viskositas dilakukan dengan menggunakan viskometer ostwald. Cairan pembanding yang digunakan adalah air. Viskositas ditentukan dengan cairan diisap sampai bagian atas tanda pada viskometer. Lubang viskometer dibuka bersamaan dengan mengatur waktu pada stopwatch. Waktu pada stopwatch dihentikan dan dicatat saat cairan tepat pada batas bawah dari tanda. perlakuan tersebut diulang sebanyak 3 kali dan ditentukan nilai rata-rata. Viskositas cairan dihitung berdasarkan persamaan

$$
\frac{n 1}{n 2}=\frac{\rho 1}{\rho 2} x \frac{t 1}{t 2}
$$

\section{Keterangan :}

n1 dan $\rho 1$ : viskositas dan densitas air $\mathrm{n} 2$ dan $\rho 2$ : viskositas dan densitas cairan yang diukur

\section{Transmitansi (Widowati dkk., 2019)}

Nilai transmitasi diukur untuk menunjukan kecerahan dari sari buah naga super merah. Sari buah naga super merah dianalisis transmitasinya dengan spektofotometer pada panjang gelombang maksimum $535 \mathrm{~nm}$ dengan aquades sebagai blanko.

\section{Penentuan Perlakuan Terbaik}

Menentukan perlakuan terbaik dari klarifikasi sari buah naga super merah berdasarkan parameter $\mathrm{pH}$, total padatan terlarut, viskositas, dan transmitansi.

\section{Rancangan Penelitian dan Analisis Data}

Faktor yang diteliti dalam penelitian ini adalah perbedaan karakter sari buah naga super merah dengan kombinasi enzim poligalakturonase dari isolat Bacillus licheniformis strain GD2a AR2 pada konsentrasi $0 \% ; 0,09 \% ; 0,1 \%$ dan gelatin pada konsentrasi $0 \% ; 1 \% ; 1,5 \%$ pada klarifikasi sari buah naga super merah (Hylocereus costaricensis) serta pengaruhnya terhadap parameter $\mathrm{pH}$, total padatan terlarut, viskositas, dan transmitasi sehingga diketahui konsentrasi enzim poligalakturonase dan konsentrasi gelatin terbaik yang digunakan pada proses klarifikasi sari buah naga super merah. Pengaruh konsentrasi enzim poligalakturonase dan konsentrasi gelatin yang digunakan pada klarifikasi sari buah naga super merah dengan pengujian $\mathrm{pH}$, total padatan terlarut, viskositas, dan transmitasi menggunakan 3 kali ulangan sampel dan 1 kali analisis. Penelitian ini menggunakan Rancangan Acak Lengkap (RAL) dengan menggunakan dua faktor (konsentrasi enzim dan konsentrasi gelatin). Data $\mathrm{pH}$, viskositas, total padatan terlarut (TPT) dan transmittansi yang diperoleh kemudian dianalisis secara 
statistik dengan menggunakan two way ANOVA pada tingkat signifikansi $5 \%$ dan dilanjutkan dengan uji Duncan Multiple Range Test (DMRT) pada tingkat signifikansi 5\%. Perlakuan terbaik ditentukan menggunakan tabel matriks.

\section{HASIL DAN PEMBAHASAN}

\section{Hasil Klarifikasi Sari Buah Naga Super Merah}

Tabel 3 menunjukkan hasil analisis klarifikasi sari buah naga super merah (Hylocereus costaricensis) dengan penambahan enzim poligalakturonase Bacillus licheniformis strain GD2a AR2 pada konsentrasi $0 \%$; $0,1 \%$; dan $0,09 \%$ dengan gelatin pada konsentrasi $0 \%$; $1 \%$; dan $1,5 \%$ berdasarkan parameter $\mathrm{pH}$, total padatan terlarut (TPT), viskositas, dan transmitansi.

1. pH

Pengukuran $\mathrm{pH}$ merupakan salah satu parameter untuk mengetahui perubahan tingkat keasaman suatu produk. Nilai $\mathrm{pH}$ merupakan minus logaritma dari konsentrasi ion $\mathrm{H}^{+}$yang dinyatakan dalam satuan mol/l. Konsentrasi ion $\mathrm{H}^{+}$ ditentukan oleh molekul-molekul yang dapat melepaskan maupun yang dapat mengikat ion ke dalam larutan (Li et al, 2015).

Pada perubahan $\mathrm{pH}$ skala kecil gugus ionik berperan dalam menjaga konformasi sisi aktif enzim untuk mengikat dan mengubah substrat menjadi Menurut Patel et al, (2013) perubahan struktur tersier enzim menyebabkan kelompok hidrofobik kontak dengan air sehingga solubilitas enzim menjadi berkurang. Berkurangnya solubilitas enzim mengakibatkan turunnya aktivitas enzim secara bertahap. Pengaruh $\mathrm{pH}$ berkaitan dengan terjadinya aktivitas enzim yang maksimal pada $\mathrm{pH}$ optimum, pada $\mathrm{pH}$ optimum ini enzim juga memiliki stabilitas tinggi, sebaliknya bila enzim berada di bawah atau di atas $\mathrm{pH}$ optimalnya maka aktivitas enzim menurun. Perubahan aktivitas enzim akibat perubahan $\mathrm{pH}$ disebabkan oleh perubahan ionisasi enzim, substrat atau kompleks enzim-substrat. Ketika $\mathrm{pH}$ lingkungan berubah, struktur tiga dimensi protein akan terganggu dan perubahan $\mathrm{pH}$ yang ekstrim akan menyebabkan denaturasi protein (Widowati et al, 2017). Hasil analisis pH sari buah naga super merah dapat dilihat pada Tabel 3.

Pada Tabel 3 dapat dilihat bahwa penambahan enzim poligalakturonase Bacillus licheniformis strain GD2a AR2 $0,09 \%$ menunjukkan pengaruh yang nyata terhadap penurunan $\mathrm{pH}$ sari buah naga super merah dengan $\mathrm{pH}$ 4,03 dibandingkan dengan kontrol dengan $\mathrm{pH}$ 4,06. Peningkatan konsentasi enzim poligalakturonase yang digunakan tidak menunjukkan pengaruh yang nyata, yaitu pada penambahan enzim poligalakturonase $0,1 \%$ dengan $\mathrm{pH} 4,04$. Penambahan enzim poligalakturonase Bacillus licheniformis strain GD2a AR2 menurunkan $\mathrm{pH}$ sari buah naga super merah seiring bertambahnya konsentrasi enzim yang digunakan karena enzim poligalakturonase menghidrolisis pektin menjadi asam galakturonat (Widowati dkk., 2019). Produksi asam galakturonat menciptakan kondisi asam pada sari buah sehingga menurunkan $\mathrm{pH}$ sari buah naga super merah ('Aliaa, et al., 2010). Penurunan $\mathrm{pH}$ sari buah akan menyebabkan penurunan total padatan terlarut yang dihitung sebagai sukrosa (Erwinda dan Susanto, 2014).

Berdasarkan Tabel 3 dapat dilihat bahwa penambahan gelatin $1 \%$ menunjukkan pengaruh yang nyata terhadap peningkatan $\mathrm{pH}$ sari buah naga super merah dengan $\mathrm{pH}$ 4,07 dibandingkan dengan kontrol dengan $\mathrm{pH}$ 3,98 . Peningkatan konsentasi gelatin yang digunakan menunjukkan pengaruh yang nyata, yaitu pada penambahan gelatin $1,5 \%$ dengan $\mathrm{pH}$ 4,09. Penambahan gelatin meningkatkan $\mathrm{pH}$ sari buah naga super merah seiring bertambahnya konsentrasi gelatin yang digunakan karena gelatin merupakan hidrokoloid yang banyak mengandung gugus karboksil yang akan terhidrolisis di dalam air sehingga akan meningkatkan $\mathrm{pH}$ sari buah naga super merah (Farikha dkk., 2013). 
Tabel 3 Hasil Analisis Klafikasi Sari Buah Naga Super Merah dengan Penambahan Enzim Poligalakturonase Bacillus licheniformis strain GD2a AR2 dan Gelatin

\begin{tabular}{|c|c|c|c|c|c|}
\hline \multirow[b]{2}{*}{ Faktor } & \multirow[b]{2}{*}{ Konsentrasi } & \multicolumn{4}{|c|}{ Parameter } \\
\hline & & $\mathrm{pH}$ & TPT $\left({ }^{0}\right.$ Brix $)$ & $\begin{array}{c}\text { Viskositas (centi } \\
\text { Poise) }\end{array}$ & $\begin{array}{c}\text { Transmitansi } \\
(\% \mathrm{~T})\end{array}$ \\
\hline \multirow[t]{3}{*}{ Enzim } & $0 \%$ & $4,06^{\mathrm{B}} \pm 0,04$ & $17,2^{\mathrm{C}} \pm 0,6$ & $10,822^{\mathrm{B}} \pm 0,201$ & $0,5^{\mathrm{A}} \pm 0,2$ \\
\hline & $0,09 \%$ & $4,03^{\mathrm{A}} \pm 0,05$ & $16,7^{\mathrm{B}} \pm 0,6$ & $10,642^{\mathrm{A}} \pm 0,156$ & $0,7^{\mathrm{B}} \pm 0,2$ \\
\hline & $0,1 \%$ & $4,04^{\mathrm{A}} \pm 0,06$ & $16,5^{\mathrm{A}} \pm 0,6$ & $10,545^{\mathrm{A}} \pm 0,135$ & $0,9^{\mathrm{C}} \pm 0,1$ \\
\hline \multirow[t]{3}{*}{ Gelatin } & $0 \%$ & $3,98^{\mathrm{a}} \pm 0,02$ & $16,0^{\mathrm{a}} \pm 0,4$ & $10,491^{\mathrm{a}} \pm 0,135$ & $0,6^{\mathrm{a}} \pm 0,3$ \\
\hline & $1 \%$ & $4,07^{\mathrm{b}} \pm 0,01$ & $17,1^{\mathrm{b}} \pm 0,4$ & $10,721^{\mathrm{b}} \pm 0,142$ & $0,7^{\mathrm{ab}} \pm 0,2$ \\
\hline & $1,5 \%$ & $4,09^{c} \pm 0,02$ & $17,3^{\mathrm{c}} \pm 0,4$ & $10,797^{\mathrm{b}} \pm 0,180$ & $0,8^{\mathrm{b}} \pm 0,2$ \\
\hline
\end{tabular}

Keterangan:

- Notasi huruf besar yang sama pada kolom yang sama menunjukkan tidak berbeda nyata pada $\alpha=$ 0,05

- Notasi huruf kecil yang sama pada kolom yang sama menunjukkan tidak berbeda nyata pada $\alpha=$ 0,05

\section{Total Padatan Terlarut (TPT)}

Total padatan terlarut (TPT) menunjukkan kandungan bahan-bahan yang terlarut dalam larutan seperti glukosa, fruktosa, sukrosa, dan pektin. Menurut Sugiyono (2010) komponen yang terukur sebagai total padatan terlarut yaitu sukrosa, gula reduksi, asam-asam organik, dan protein. Kandungan utama total padatan terlarut pada sari buah adalah sukrosa (Rehman et al, 2012) yang dinyatakan dalam satuan ${ }^{0}$ brix. Derajat Brix adalah zat padat kering yang terlarut dalam suatu larutan dihitung sebagai sukrosa. Analisis total padatan terlarut menggunakan alat hand refractometer (ATAGO) berbasis gula (sukrosa). Hand refraktometer bekerja dengan prinsip pembiasan cahaya pada suatu larutan. Prinsip ini digunakan untuk menentukan zat terlarut dalam larutan dengan melewatkan cahaya di dalamnya. Nilai ${ }^{0}$ brix semakin tinggi saat kadar sukrosa meningkat (Widowati et al., 2017).

Pada Tabel 3 dapat dilihat bahwa penambahan enzim poligalakturonase Bacillus licheniformis strain GD2a AR2 $0,09 \%$ menunjukkan pengaruh yang nyata terhadap penurunan TPT sari buah naga super merah dengan TPT $16,7^{0}$ Brix dibandingkan dengan kontrol dengan TPT $17,2^{0}$ Brix. Peningkatan konsentasi enzim poligalakturonase yang digunakan menunjukkan pengaruh yang nyata, yaitu pada penambahan enzim poligalakturonase $0,1 \%$ dengan TPT
16,, $5^{\circ}$ Brix. Penambahan enzim poligalakturonase Bacillus licheniformis strain GD2a AR2 menurunkan $\mathrm{pH}$ sari buah naga super merah seiring bertambahnya konsentrasi enzim yang digunakan karena enzim poligalakturonase menghidrolisis pektin menjadi asam galakturonat (Widowati et $a l$, 2017). Produksi asam galakturonat menciptakan kondisi asam pada sari buah sehingga menurunkan $\mathrm{pH}$ sari buah naga super merah ("Aliaa, et al., 2010). Penurunan $\mathrm{pH}$ akan menurunkan total padatan terlarut karena sukrosa dalam kondisi asam akan terhidrolisis menjadi gula invert yaitu fruktosa dan glukosa (Erwinda dan Susanto, 2014). Penurunan TPT sari buah akan menyebabkan penurunan viskositas (Pratama, 2013). Dengan berkurangnya sukrosa maka viskositas sari buah naga super merah akan menurun. Hasil analisis viskositas dapat dilihat pada Tabel 3.

Berdasarkan Tabel 3 dapat dilihat bahwa penambahan gelatin $1 \%$ menunjukkan pengaruh yang nyata terhadap peningkatan TPT sari buah naga super merah dengan TPT $17,1^{\circ}$ Brix dibandingkan dengan kontrol dengan TPT $16,0^{0}$ Brix. Peningkatan konsentasi gelatin yang digunakan menunjukkan pengaruh yang nyata, yaitu pada penambahan gelatin $1,5 \%$ dengan TPT $17,3^{\circ}$ Brix. Penambahan gelatin meningkatkan TPT sari buah naga super merah seiring bertambahnya konsentrasi gelatin yang 
digunakan karena gelatin mampu mengikat partikel yang berada dalam sari buah sehingga mencegah pengendapan. Total padatan terlarut meningkat karena air bebas diikat oleh gelatin sehingga konsentrasi bahan yang larut meningkat. Semakin banyak partikel yang terikat oleh gelatin maka total padatan terlarut juga akan semakin meningkat dan mengurangi endapan yang terbentuk. Dengan adanya gelatin maka partikel-partikel yang tersuspensi akan terperangkap dalam sistem tersebut dan tidak mengendap oleh pengaruh gaya gravitasi (Farikha dkk, 2013).

Gelatin dapat berubah secara reversibel dari bentuk sol ke bentuk gel. Pembentukan gel gelatin terjadi karena pengembangan molekul gelatin akibat pemanasan. Panas akan membuka ikatanikatan molekul gelatin dan gugus hidrofobik dari protein gelatin berada di permukaan sedangkan gugus hidrofiliknya berada di dalam sehingga terjadi ikatan antara gugus $\mathrm{COO}^{-}, \mathrm{NH}_{3}$, dan $\mathrm{H}_{2} \mathrm{O}$ yang membentuk ikatan silang pada molekul gelatin yang menyebabkan cairan yang awalnya bebas menjadi terperangkap dalam sistem tersebut (Sharma et al., 2014)

\section{Viskositas}

Viskositas merupakan tolak ukur suatu sari buah memiliki kandungan pulp dan komponen lain seperti pektin dalam jumlah tertentu. Masing-masing jenis sari buah mempunyai viskositas yang berbedabeda berkaitan dengan kandungan yang dimiliki oleh buah yang menjadi bahan dasar sari buah tersebut. Kandungan pektin yang tinggi pada buah akan menghasilkan sari buah dengan viskositas yang tinggi pula. Semakin tinggi viskositas maka semakin kental sari buah tersebut. Sari buah dengan viskositas tinggi menimbulkan masalah selama proses filtrasi sehingga mengurangi hasil rendemen, sehingga diperlukan enzim untuk menghidrolisis polisakarida terlarut yang berperan penting terhadap tingginya viskositas.

Pada Tabel 3 dapat dilihat bahwa penambahan enzim poligalakturonase isolat Bacillus licheniformis strain GD2a AR2 0,09\% menunjukkan pengaruh yang nyata terhadap penurunan viskositas sari buah naga super merah dengan viskositas $10,6418 \mathrm{cP}$ dibandingkan dengan kontrol dengan viskositas $10,8222 \mathrm{cP}$. Peningkatan konsentasi enzim poligalakturonase yang digunakan tidak menunjukkan pengaruh yang nyata, yaitu pada penambahan enzim poligalakturonase $0,1 \%$ dengan viskositas 10,5451cP. Penambahan enzim poligalakturonase Bacillus licheniformis strain GD2a AR2 menurunkan $\mathrm{pH}$ sari buah naga super merah seiring bertambahnya konsentrasi enzim yang digunakan karena enzim poligalakturonase menghidrolisis pektin menjadi asam galakturonat yang berdampak pada penurunan kapasitas ikat air yang mengakibatkan air bebas dilepaskan pada sistem sehingga menurunkan viskositas sari buah (Sandri dan da Silveira, 2018). Penurunan viskositas juga terjadi karena enzim poligalakturonase menghidrolisis pektin menjadi asam galakturonat, produksi asam galakturonat menciptakan kondisi asam pada sari buah sehingga menurunkan $\mathrm{pH}$ sari buah naga super merah ('Aliaa, et al., 2010). Penurunan $\mathrm{pH}$ akan menurunkan total padatan terlarut karena sukrosa dalam kondisi asam akan terhidrolisis menjadi gula invert yaitu fruktosa dan glukosa (Erwinda dan Susanto, 2014). Penurunan TPT akan menyebabkan penurunan viskositas sari buah (Pratama, 2013). Dengan semakin berkurangnya viskositas sari buah naga super merah menunjukkan semakin banyaknya pektin yang terhidrolisis yang akan meningkatan transmitansi sari buah.

Penambahan gelatin $1 \%$ menunjukkan pengaruh yang nyata terhadap peningkatan viskositas sari buah naga super merah dengan viskositas $10,7214 \mathrm{cP}$ dibandingkan dengan kontrol dengan viskositas 10,4912cP. Peningkatan konsentasi gelatin yang digunakan tidak menunjukkan pengaruh yang nyata, yaitu pada penambahan gelatin $1,5 \%$ dengan viskositas $10,7967 \mathrm{cP}$. Penambahan gelatin meningkatkan viskositas sari buah naga 
super merah seiring bertambahnya konsentrasi gelatin yang digunakan karena gelatin bersifat hidrofilik yang akan menyerap air pada sari buah sehingga terjadi peningkatan viskositas (Sandri dan da Silveira, 2018).

\section{Transmitansi}

Transmitansi merupakan bagian dari cahaya yang diteruskan melalui larutan. Tingkat kejernihan larutan ditentukan oleh luas permukaan \%transmitan, semakin besar \%transmitan menunjukkan semakin jernih larutan. Pektin merupakan substansi terpenting yang menyebabkan kekeruhan. Aplikasi enzim dapat mereduksi kekeruhan dengan cara mendegradasi kandungan pektin dalam sari buah. Tujuan analisis transmitansi untuk mengetahui pengaruh klarifikasi terhadap tingkat kecerahan sari buah naga super merah. Klarifikasi sari buah naga super merah menggunakan spektrofotometer dengan panjang gelombang $(\lambda)$ maksimum yaitu $535 \mathrm{~nm}$, panjang gelombang maksimum digunakan untuk mengetahui seberapa besar energi cahaya tertinggi yang dapat diserap oleh larutan.

Selain itu penambahan gelatin dapat menjernihkan sari buah karena gelatin mampu menyerap kandungan-kandungan yang dapat menyebabkan sari buah keruh seperti tanin dengan berkoagulasi. Tanin terdiri dari katekin, leukoantosianin dan asam hidroksi yang masing-masing dapat menimbulkan warna bila bereaksi dengan ion logam. Senyawa-senyawa yang dapat bereaksi dengan protein dalam proses penyamakan kulit kemungkinan besar terdiri dari katekin dengan berat molekul sedang, sedangkan katekin dengan berat molekul rendah banyak ditemukan pada buah-buahan dan sayuran Sharma et al., 2014).

Istilah tanin yang digunakan dalam bidang pangan ada dua macam. Tipe pertama adalah condensed tannin yang merupakan polimer dari katekin (flavan-3ol) dan leukoantosianin (flavan-3,4-diol). Bentuk kedua adalah hydrolysable 8 tannin, termasuk di dalamnya senyawasenyawa galotanin dan elagitanin. Senyawa tanin terkondensasi tidak dapat dihidrolisa baik oleh asam, basa maupun enzim. Sedangkan tanin terhidrolisis terdiri dari senyawa poliester dan glikosida yang satu sama lainnya dihubungkan oleh atom $\mathrm{O}$ dan mudah terhidrolisis dengan asam dan enzim. Tanin yang terkondensasi terdapat pada buah-buahan, biji-bijian dan tanaman yang dapat dimanfaatkan manusia sebagai makanan, sedangkan tanin yang dapat dihidrolisa banyak terdapat pada kelompok tanaman bukan makanan (non edible food), tetapi mempunyai peranan penting dalam industri makanan, minuman dan obat-obatan (Sharma et al., 2014). Oleh karena itu transmitansi digunakan untuk mendeteksi tingkat kejernihan sari buah dan seberapa besar pengaruh enzim dan gelatin dalam mereduksi kekeruhan.

Pada Tabel 3 dapat dilihat bahwa penambahan enzim poligalakturonase Bacillus licheniformis strain GD2a AR2 $0,09 \%$ menunjukkan pengaruh yang nyata terhadap peningkatan transmitansi sari buah naga super merah dengan transmitansi $0,7 \% \mathrm{~T}$ dibandingkan dengan kontrol dengan transmitansi 0,5\% $\mathrm{T}$. Peningkatan konsentasi enzim poligalakturonase yang digunakan menunjukkan pengaruh yang nyata, yaitu pada penambahan enzim poligalakturonase $\quad 0,1 \% \quad$ dengan transmitansi $0,9 \%$ T. Penambahan enzim poligalakturonase Bacillus licheniformis strain GD2a AR2 meningkatkan transmitansi sari buah naga super merah seiring bertambahnya konsentrasi enzim yang digunakan karena enzim poligalakturonase mereduksi kekeruhan dengan cara mendegradasi pektin yang merupakan substansi yang menyebabkan kekeruhan dalam sari buah. Enzim poligalakturonase dapat meningkatkan transmitansi dengan mekanisme pemotongan pektin. Pektin pada umumnya terdiri dari senyawa karbohidrat yang senyawa utamanya adalah poligalakturonat yang terdiri dari unit galakturonat. Ketika sari buah ditambahkan enzim poligalakturonase, ikatan poligalakturonat akan diputus 
sehingga molekul poligakturonat berubah menjadi lebih kecil (asam galakturonat) yang berdampak pada meningkatnya luas permukaan \%transmitan sehingga semakin banyak cahaya yang diteruskan melalui larutan, semakin besar \%transmitan menunjukkan semakin jernih larutan. Peningkatan transmitansi juga terjadi karena enzim poligalakturonase menghidrolisis pektin menjadi asam galakturonat. Produksi asam galakturonat menciptakan kondisi asam pada sari buah sehingga menurunkan $\mathrm{pH}$ sari buah naga super merah ('Aliaa, et al., 2010). Penurunan $\mathrm{pH}$ akan menurunkan total padatan terlarut karena sukrosa dalam kondisi asam akan terhidrolisis menjadi gula invert yaitu fruktosa dan glukosa (Erwinda dan Susanto, 2014). Penurunan TPT akan menyebabkan penurunan viskositas sari buah (Pratama, 2013). Dengan semakin berkurangnya viskositas sari buah naga super merah menunjukkan semakin banyaknya pektin yang terhidrolisis yang akan meningkatan transmitansi sari buah.

Berdasarkan Tabel 3 dapat dilihat bahwa penambahan gelatin $1 \%$ tidak menunjukkan pengaruh yang nyata terhadap peningkatan transmitansi sari buah naga super merah dengan transmitansi $0,7 \% \mathrm{~T}$ dibandingkan dengan kontrol dengan transmitansi 0,6\% $\mathrm{T}$. Peningkatan konsentasi gelatin yang digunakan tidak menunjukkan pengaruh yang nyata, yaitu pada penambahan gelatin $1,5 \%$ dengan transmitansi $0,8 \% \mathrm{~T}$. Penambahan gelatin meningkatkan transmitansi sari buah naga super merah seiring bertambahnya konsentrasi gelatin yang digunakan karena gelatin mampu menyerap kandungan-kandungan yang dapat menyebabkan sari buah keruh seperti tanin dengan berkoagulasi. Gelatin dapat terkoagulasi oleh asam dan juga panas. Efektifitas pembentukan ikatan silang protein dan tanin sangat dipengaruhi oleh ukuran molekul tanin. Umumnya tanin berukuran sedang (oligomer) menunjukkan efektifitas yang tinggi dalam membentuk ikatan silang.
Tanin berukuran kecil (monomer) tidak mampu membentuk ikatan silang yang efektif. Sedangkan tanin berukuran besar (polimer) sangat tidak larut atau terlalu besar untuk berikatan dengan protein. Interaksi gelatin dengan tanin sama dengan interaksi protein-tanin, karena gelatin tersusun dari asam-asam amino. Terdapat empat tipe ikatan yang terbentuk dalam interaksi protein-tanin yaitu ikatan hidrogen, ikatan kovalen, ikatan ionik dan ikatan hidrofobik. Ikatan hidrogen bersifat reversible. Ikatan ini terjadi antara gugus karboksil dari ikatan peptida dengan gugus hidroksil dari tanin. Ikatan hidrogen merupakan yang dominan dalam kompleks protein-tanin. Sedangkan ikatan kovalen terjadi bila tanin telah mengalami oksidasi dan membentuk polimer kuinon. Ikatan kovalen antara protein-tanin merupakan ikatan yang paling stabil diantara ikatan lainnya. Jenis ikatan lain seperti ikatan ionik juga terdapat pada komplek protein-tanin, tetapi peranannya sedikit sekali dibandingkan dengan kedua ikatan diatas (Winarno, 1992).

Selain mengikat tanin, gelatin juga dapat digunakan sebagai penjernih ketika gelatin tersebut didenaturasi. Menurut Winarno (1992) denaturasi dapat diartikan suatu perubahan atau modifikasi terhadap struktur sekunder, tersier, dan kuartener terhadap molekul protein, tanpa terjadinya pemecahan ikatan-ikatan kovalen. Denaturasi protein dapat disebabkan oleh panas, $\mathrm{pH}$, senyawa kimia (urea dan garam guanidia), mekanik, dan sebagainya. Pemekaran atau pengembangan molekul protein yang terdenaturasi akan membuka gugus reaktif yang ada pada rantai polipeptida. Selanjutnya akan terjadi pengikatan kembali pada gugus reaktif yang sama atau yang berdekatan. Bila unit ikatan yang terbentuk cukup banyak sehingga protein tidak lagi terdispersi sebagai suatu koloid, maka protein tersebut mengalami koagulasi.

\section{Perlakuan Terbaik}

Untuk lebih lanjut ingin diketahui juga konsentrasi enzim poligalakturonase dan 
konsentrasi gelatin terbaik yang digunakan pada proses klarifikasi sari buah naga super merah. Oleh karena itu, dari data yang didapatkan pada penelitian kemudian dibuat matriks untuk memilih perlakuan terbaik dari klarifikasi sari buah naga super merah yang telah dilakukan. Pemilihan perlakuan terbaik secara deskriptif berdasarkan pengaruh enzim dan gelatin terhadap $\mathrm{pH}$, TPT, viskositas dan transmittansi.
Perlakuan terpilih pada sampel dengan penambahan enzim poligalakturonase isolat Bacillus licheniformis strain GD2a AR2 $0,1 \%$. Penambahan enzim poligalakturonase pada konsentrasi $0,1 \%$ menurunkan $\mathrm{pH}$, total padatan terlarut, dan viskositas serta meningkatkan transmitansi sari buah naga super merah (Tabel 4).

Tabel 4 Penentuan Konsentrasi Enzim Poligalakturonase Bacillus licheniformis strain GD2a AR2 dan Gelatin Terbaik Berdasarkan Faktor pH, Total Padatan Terlarut, Viskositas, dan Transmitansi, pH) pada Sari Buah Naga Super Merah

\begin{tabular}{lccccc}
\hline \multicolumn{1}{c}{ Sampel } & \multicolumn{5}{c}{ Sari buah } \\
\cline { 2 - 6 } & $\mathrm{pH}$ & $\mathrm{TPT}$ & Viskositas & $\begin{array}{c}\text { Transmitansi } \\
(\% \mathrm{~T})\end{array}$ & Jumlah \\
\hline Kontrol & $4,01^{\mathrm{b}}$ & $16,5^{\mathrm{c}}$ & $10,6209^{\mathrm{bc}}$ & $0,3^{\mathrm{a}}$ & 0 \\
Enzim 0\%; gelatin 1\% & $4,07^{\mathrm{c}}$ & $17,5^{\mathrm{f}}$ & $10,8481^{\mathrm{de}}$ & $0,5^{\mathrm{ab}}$ & 0 \\
Enzim 0\%; gelatin 1,5\% & $\mathbf{4 , 1 1}^{\mathrm{e}}$ & $17,7^{\mathrm{f}}$ & $10,9972^{\mathrm{e}}$ & $0,7^{\mathrm{bc}}$ & $\mathbf{1}$ \\
Enzim 0,09\%; gelatin 0\% & $3,97^{\mathrm{a}}$ & $16,0^{\mathrm{b}}$ & $\mathbf{1 0 , 4 5 6 4 ^ { \mathrm { ab } }}$ & $0,6^{\text {bc }}$ & $\mathbf{1}$ \\
Enzim 0,09\%; gelatin 1\% & $4,06^{\mathrm{c}}$ & $17,0^{\mathrm{de}}$ & $10,7175^{\mathrm{cd}}$ & $\mathbf{0 , 7}^{\text {bcd }}$ & $\mathbf{1}$ \\
Enzim 0,09\%; gelatin 1,5\% & $4,07^{\mathrm{c}}$ & $17,1^{\mathrm{e}}$ & $10,7576^{\mathrm{cd}}$ & $\mathbf{0 , 8}^{\text {bcd }}$ & $\mathbf{1}$ \\
Enzim 0,1\%; gelatin 0\% & $3,97^{\mathrm{a}}$ & $\mathbf{1 5 , 7}^{\mathrm{a}}$ & $\mathbf{1 0 , 3 9 5 7}^{\mathrm{a}}$ & $\mathbf{0 , 8}^{\text {bcd }}$ & $\mathbf{3}$ \\
Enzim 0,1\%; gelatin 1\% & $4,07^{\mathrm{c}}$ & $16,7^{\mathrm{d}}$ & $10,6044^{\mathrm{bc}}$ & $\mathbf{0 , 9}^{\text {cd }}$ & $\mathbf{1}$ \\
Enzim 0,1\%; gelatin 1,5\% & $4,09^{\mathrm{d}}$ & $17,0^{\mathrm{de}}$ & $10,6353^{\mathrm{bc}}$ & $\mathbf{1 , 0}^{\text {d }}$ & $\mathbf{1}$ \\
\hline
\end{tabular}

\section{KESIMPULAN}

Berdasarkan hasil penelitian maka dapat diambil kesimpulan bahwa penambahan enzim poligalakturonase menurunkan $\mathrm{pH}$, total padatan terlarut, dan viskositasnya serta meningkatkan transmitansi seiring bertambahnya konsentrasi yang digunakan. Penambahan gelatin meningkatkan $\mathrm{pH}$, total padatan terlarut, viskositas, dan transmitansi seiring bertambahnya konsentrasi yang digunakan. Perlakuan terpilih pada sampel dengan penambahan enzim poligalakturonase isolat Bacillus licheniformis strain GD2a AR2 $0,1 \%$. Penambahan enzim poligalakturonase pada konsentrasi $0,1 \%$ menurunkan $\mathrm{pH}$, total padatan terlarut, dan viskositas serta meningkatkan transmitansi sari buah naga super merah.

\section{DAFTAR PUSTAKA}

Akesowan, A. dan Choonhahirun, A. (2013). Effect of enzyme treatment on guava juice production using response surface methodology. Journal Animal
Plant Science 23 (1): 114-120.

'Aliaa, A.R.N., S. Mazlina, M.K. dan Taip, F.S. (2010). Impact of Commercial Pectolytic Enzymes on Selected Properties of White Dragon Fruit Juice. Department of Process and Food Engineering, Faculty of Engineering, Universiti Putra Malaysia, 43400 UPM, Serdang, Selangor.

Badan Standarisasi Nasional. (1995). Minuman Sari Buah. SNI 01-37191995. Jakarta.

Direktorat Jenderal Industri Agro dan Kimia. (2010). Roadmap Industri Pengolahan Buah. Departemen Perindustrian. Jakarta.

Erwinda,M.D. dan Susanto, W.H. (2014). Pengaruh $\mathrm{pH}$ nira tebu (Saccharum officinarum) dan konsentrasi penambahan kapur terhadap kualitas gula merah. Jurnal Pangan dan Agroindustri 2 (3): 54-64.

Farikha, I.N., Anam, C.dan Widowati, E. (2013). Pengaruh jenis dan 
konsentrasi bahan penstabil alami terhadap karakteristik fisikokimia sari buah naga merah (Hylocereus polyrhizus) selama penyimpanan. Jurnal Teknosains Pangan 2(1): 30-38.

Khalil, T.A. (2013). Effect of Fungal Pectinases and Gelatin on Apple Juice Clarification. Department Food Science, College of Agriculture and Forestry, Mosul. University of Iraq.

Li, Q., Anthony. M., Coffman, dan LuKwang Ju. 2015. Development of reproducible assays for polygalacturonase and pectinase. Journal Enzyme and Microbial Technology 72: 42-48.

Patel, R K., Mait, C.S., Bidyut, C.D, Deshmukh, N.A, dan Nath, A. (2013). Changes in sugars, pectin and antioxidants of guava (Psidium Guajava) fruits during fruit growth and maturity. Indian Journal of Agricultural Sciences 83(10): 1017-1021.

Pratama, S.B., Wijana, S. dan Febriyanto, A. (2013). Studi pembuatan sirup tamarillo (kajian perbandingan buah dan konsentrasi gula). Jurnal Industria 1(3) : 180 - 193.

Sandri, I.G, dan da Silveira, M.M. (2018). Production and application of pectinases from Aspergillus niger obtained in solid state cultivation. Beverages 4(3):1-10. DOI : 10.3390/beverages 4030048 .

Sharma, H. P., Hiral P, dan Sugandha S. (2014). Enzymatic extraction and clarification of juice from various fruitsA Review. Trends in Post Harvest Technology 2(1): 2.

Singh, A, Sanjay K, dan Sharma, H.K. (2012). Effect of enzymatic hydrolysis on the juice yield from bael fruit (Aegle maemelos Correa) Pulp. American Journal of Food Technology 7(9): 64.

Soedarya, A.P. (2013). Agribisnis Buah Naga. Pustaka Grafika. Bandung.

Sugiyono. (2010). Ilmu Pengetahuan Bahan Pangan. Alfabeta. Bandung.
Utami, R., Widowati, E, dan Rahayu, A. (2015). Screening dan karakterisasi pektinesterase sebagai enzim potensial dalam klarifikasi sari buah jeruk keprok garut (Citrus nobilis Var.Chrysocarpa). Jurnal Agritech, 35(4), 422-433. http://doi.org/10.22146/agritech.9326.

Widowati,E., Utami, R., dan Khalistyatika, K. (2017). Screening and characterization of polygalacturonase as potential enzyme for keprok garut orange (Citrus nobilis var chrysocarpa) Juice Clarification. Journal of Physics: Conference of Series 909 (1), 012088.

Widowati, E., Sari, A.M., dan Ningsih, R.S. (2019). Kombinasi enzim poligalakturonase dan enzim pektinesterase pada klarifikasi sari buah naga super merah (Hylocereus costaricensis) dalam Pembuatan Sirup. Jurnal Teknologi Hasil Pertanian. 12(1): 29-37. 